\title{
Blockchain Technology Concept for Improving Supply Chain Traceability in the Ivory Market
}

Norman Gwangwava, Botswana International University of Science and Technology, Botswana

\begin{abstract}
Supply chain traceability is gaining momentum as a means to gain visibility across the supply chain. In order to curb poaching in the wildlife sector and harvesting of resources such as ivory, there is a need to introduce foolproof technologies. This article proposes the use of blockchain in tracing the supply chain of ivory and other wildlife products from source to destination. The article is based on a literature review on wildlife practices. Ivory trade participants were identified and mapped into a blockchain model using blockchain modeling techniques. The proposed blockchain approach allows transaction recording as blocks and visibility to relevant participants.
\end{abstract}

\section{KEYWORDS}

Blockchain, Internet of Things (IoT), Ivory, Public Ledger, Supply Chain, Traceability, Wildlife Poaching

\section{INTRODUCTION}

\section{Motivation}

Supply chain traceability is gaining momentum as a means to gain visibility across the entire supply chain. Advancements in technologies such as cloud computing and internet of things (IoT) are making traceability possible. In order to restore sanity and dignity to the wildlife sector and harvesting of the precious resources such as ivory, there is need to introduce full proof technologies such as blockchain in order to gain traceability. The technology is envisaged to identify any counterfeiting and nab the culprits. This article proposes use of blockchain in tracing the supply chain of ivory and any other wildlife products, from source to destination. Murky dealings in the wildlife supply chains have led to the adverse effects of poaching and threatening extinction of some species. In other industries, such as the food industry, where domesticated animals are the source of produce, there is better management to ensure sustainability. Production methods have been perfected, supply chains have been optimized, and recently there is more emphasis on Chains of Consensus (CoC). The value chain systems have been well developed to include certifications, monitoring and control at crucial stages. Loopholes such as stock theft have been effectively curtailed. Every value chain system needs corporation in order to be effective. Rather than advocating for complete ban of the ivory market and other wildlife products, there is need to bring corporation, transparency, and traceability in the value chain for wildlife products. Through corporation at various levels, murky dealings can be eliminated. 


\section{Literature}

Elephants are among wildlife classified under the endangered species (CITES, 2017). The demand for wildlife products is viewed as the driver for fast depletion of the wildlife resources across the world. When there is no market for the wildlife and associated products, the risk of extinction will be significantly suppressed. Natural death is by far a minor threat to most of flora and fauna. Although efforts have been made to restrict trade in the endangered species, informal markets propped up and are significantly threatening a complete disappearance of the endangered species. Poaching of wildlife is seriously condemned worldwide. Poachers kill elephants and other wild animals with cruelty. They hastily hack off the tasks, cover the animal with shrubs and disappear. Covering of the animal is meant to disguise the rangers until later when the animal starts decomposing. The sight of a ruthlessly killed animal is loathsome to tourists. Poaching adversely affects tourism and the whole value chain of wildlife products. Culling and cropping is also viewed as unethical. Some argue that when executed properly, the process is none disturbing.

Africa is home to most of the natural and wildlife resources and her economy depends on the resources. Africa is believed to have been home to around 20 million elephants before the European colonization. Only 1.3 million elephants remained by 1979 (McKenzie \& Formanek, 2016). The total population of elephants in African Savannah to date is estimated to be 352, 271 (Chase et al., 2016). The elephant population in Botswana alone is just below a third of the continent's remaining Savannah elephant population. There are many reasons attributed to the huge population concentration in Botswana compared to other countries. These range from strict control of anti-poaching to little disturbance of the large wild herds. Botswana suspended elephant trophy hunting in 2014 and mooted the shoot to kill policy as part of the measures to curb poaching of the elephants for their ivory. Unlike other countries with huge human population, Botswana's population is around 2 million people. The country has huge safari parks and game reserves. Every other resource, natural resources and wildlife, is threatened by extinction. Efficient management techniques are necessary to ensure longevity of existence. When dealing with wildlife, ethics also come into consideration. A host of management practices used to control elephants are: (a) enlarging the range available to elephants, (b) fencing to contain or exclude elephants, (c) the use of repellents, (d) translocation, (e) driving/disturbance, and $(f)$ cropping and culling. Some methods are non-lethal and favorable, whilst others are lethal and unfavourable (Cumming \& Jones, 2005; Seloana, Potgieter, Kruger, \& Jordaan, 2017; Seloana, Kruger, Potgieter, \& Jordaan, 2017). Contribution based on literature and current practice in the ivory market, as well as blockchain initiatives, ivory trade participants and the traditional supply chain were identified. The participants were then mapped into a blockchain model. The concept uses blockchain modeling techniques. The proposed blockchain approach allows every transaction to be recorded as a block in the chain and is visible to relevant participants. The blocks of information cannot be tempered with since any change to the recorded information will break the chain. The blockchain solution is sustainable, whilst benefiting host countries and formal international markets relying on wildlife. Paper Organization The article is organized into four subsequent sections. The literature review section covers literature on elephant management, economic value and products derived from elephants. The section on proposed supply chain model for ivory reviews practices on modern supply chains. Further aspects addressed include modelling the blockchain based supply chain model for tracking elephants and ivory. This is followed by the discussion section, which discusses the proposed model. The last section is the conclusion. This summarises the research, future direction, and limitations.

\section{LITERATURE REVIEW}

The article is based on literature review on the current wildlife practices and blockchain initiatives. Current trends and challenges faced by wildlife and national parks authorities are presented in this 
Table 1. Elephant management options

\begin{tabular}{|l|l|}
\hline Passive Methods & Active Methods \\
\hline Taking no action & Contraception \\
\hline Enlarging the range available to elephants & Translocation \\
\hline Fencing to contain or exclude elephants & Driving or disturbance \\
\hline Using repellents & $\begin{array}{l}\text { Culling and cropping; } \\
\text { (a) should be a targeted rather than a blanket reduction } \\
\text { exercise, } \\
\text { (b) should be carried out by thoroughly trained and } \\
\text { competent teams, } \\
\text { (c) needs to be thoroughly justified on scientific or other } \\
\text { grounds, } \\
\text { (d) all products should be recovered, and } \\
\text { (e) should benefit local communities and contribute to the } \\
\text { alleviation of poverty. }\end{array}$ \\
\hline Manipulating water supplies & \\
\hline
\end{tabular}

section. Ivory trade participants and the traditional supply chain are identified, resulting in the subsequent mapping of a blockchain model.

\section{Elephant Management}

There are two categories of elephant management options, classified as passive and active methods (Cumming, \& Jones, 2005; Bertschinger, Kirkpatrick, Fayrer-Hosken, Grobler, \& Van Altena, 2003). Table 1 summaries the specific methods that fall under each category.

Passive methods are the most preferred because they are more ethical, whilst active methods are viewed as unethical and therefore less preferred. Active methods are used where the population of wildlife is increasing beyond sustainable levels. The methods suppress population growth. Culling and cropping operations have been used before at the Hwange National Park in Zimbabwe during the 1980s. The operations were targeting elephants in the peripherals of the designated safaris and national parks. Culling needs to be done professionally in order to look humane. Hunting and culling disturbs tourism if not executed discretely. The operation can be expensive and causes stress.

Elephants without boarders (EWB), a none profit organisation, has been conducting aerial surveys in African Savannah countries (Angola, Botswana, Namibia, and Zambia). The surveys provide wildlife population data, which informs better management and conservation from a scientific perspective (Chase, Schlossberg, Sutcliffe, \& Seonyatseng, 2018). Due to the sensitivity and political nature of the wildlife subject, there is always conflict in terms of accepting the findings. It has been a regular practice that government authorities initially reject the facts from published reports. The fresh scenario is where the government of Botswana dismissed findings by Mike Chasse, rather providing figures for elephant population that is in the range of $270000-300000$, instead of the approximately 130000 that was in the official report (EWB, 2019; Thalefang, 2018). The Botswana government authorities based their estimates on the surveys by the Department of Wildlife and National Parks (DWNP). Another reasoning was that there is likelihood of population growth from the last surveys done in 2014. The elephant survey results from Great Elephant Census showed that there were 352,271 African Savannah elephants in 18 countries (Chase et al., 2016). When elephants are facing threat from natural or artificial factors, they migrate to safe havens. Botswana has been a safe haven to elephants due to its anti-poaching stance. There is likelihood of growing numbers from elephants migrating into the country. In the year 2005, WWF reported an elephant population of approximately 150, 000 in Botswana and about 100, 000 in Zimbabwe. The total elephant population in Southern Africa was estimated to reach greater than 500, 000 by 2020 if the growth rate was 
maintained (Cumming, \& Jones, 2005). The truth is the growth rate was never maintained due to rampant poaching in other countries. During the period 2013-2016, there was serious poaching and cyanide poisoning of elephants in Hwange National Park, Zimbabwe.

Policy and political will are important factors that influence management of wildlife resources. If local government authorities show less commitment formulating effective policies and making serious efforts to enforce laws and policies, that exposes wildlife to murky dealings. The international community is of the perspective that income streams from wildlife trade is used to finance terrorist groups and governments of terror in some African nations. Botswana has for the past five years demonstrated strong political and will power to curtail any detrimental practices on their wildlife. In the year 2014, the government suspended the elephant hunting trophy, followed by stern measures such as arming of the rangers and launching the shoot to kill policy. The measures have been effective and saw the ballooning elephant population, by birth and migration from other surrounding countries which pose a threat to the elephants. Although this is good news to the tourism industry, the local citizens are pilling pressure on their political representatives to do something to prevent further human-elephant conflicts and more damage to their crops and communal land.

\section{Economic Value of Elephants and Products}

Wildlife has great economic benefits which come from tourism, live trading and selling of processed products. Elephants attract tourists, their tusks can be harvested for ivory products, skins have high value for leather apparel, and meat products are human palatable, as well as feeding pets.

\section{Ivory Trade}

Ivory trade is regulated by national and international laws. This is meant to protect wildlife due to biodiversity effects if the situation is left unguarded. Elephant tusks are harvested for making ivory products (Stiles, 2004). Two main sources of tusks are from wild elephants and domesticated elephants. Laws allow private people to own fenced areas where they keep animals. Private companies or individuals may trim tusk tips from their domesticated elephants and sell to individuals or companies that make finished products. Tusks can also be harvested from elephants that die naturally. Large size tusks may be supplied from culled or cropped elephants. Government authorities used to hold open auctions on stockpiles of their ivory accumulated over time from naturally dying, and or culled elephants. Both formal (legal) and informal (illegal) markets exist in ivory trading.

Illegal stakeholders in the informal market include poachers, smugglers, illegal producers and ultimate consumers (Brennan, \& Kalsi, 2015; Bennett, 2015). Official stakeholders are the wildlife and national parks authorities, conservationists, law enforcement community, producers and purchasers of ivory products. The stakeholders are participants in the supply chain. In any supply chain, there is flow of information and materials. Various means of communication are used to pass information throughout the supply chain. Material flow is aided through transport and logistics methods such as road, airlines, and ships. In case of illegal movement, the tusks and other products are concealed in cargo containers and other official packages (Vigne, \& Martin, 2018).

Importing countries have established value chains for ivory and other wildlife products. Carvers are specialized tradesmen who shape physical materials such as wood and tusks into decorative finished artefacts. These carvers are either hired by shop owners who sell ivory products or are themselves business owners who shape items for sale. Due to lack of systems for traceability, once the ivory lands in the hands of carvers, wholesalers and retailers, it is difficult to tell whether it's been sourced formally or informally. There has been reports of DNA testing to establish the source of the ivory and the time of death of the elephant but it's not a widely adopted practice and it's also expensive (Winters et al., 2018). Carvers can use simple hand tools or advanced computer numerical control (CNC) machines to produce artefacts for sale. The jewellery industry is characterized by unique end user needs, hence most of the items require specialized shaping and artwork. This makes the 
industry more of mass customization oriented than mass production. Demand is also not very high and constant. Most people who buy ivory products are tourists who have erratic and seasonal arrivals.

\section{Tourism}

Tourism industry in Botswana has grown tremendously over the past years (Duffy, 2014). This has benefited local communities through thousands of job creation, opportunities for training and skills transfers. Since the growth mainly occurred during the suspension of elephant hunting trophy, it is not clear what would happen after bringing back the hunting trophy. Between 2013 (the last year of hunting) and 2018, tourism in the country grew its contribution to Botswana's GDP by a staggering $70 \%$. In 2017 it contributed over \$2-billion to the economy and provided 76,000 jobs. Tourism investment for that year was \$443-million (Pinnock, 2019).

Private investors have been on the lead of tourism industry growth than the public sector. Tourist attractions to Botswana are driven by wilderness and wildlife experience. The country hosts the Okavango Delta (the world's largest inland delta), Chobe National Park (carries large numbers and varieties of game), Kgalagadi Trans-frontier Park (trans-boundary park in Africa), Central Kalahari Game Reserve (one of largest game reserves in Africa), and the Makgadikgadi and Nxai Pans National Park (Mbaiwa, 2008). Botswana is among the three most preferred tourist destinations in Southern Africa (South Africa, Zimbabwe, and Botswana respectively). Since 1990 Botswana's government has been heavily supporting tourism as part of its economic diversification program (Kalikawe, 2001).

\section{Live Elephant Sales}

Appendix II listing and various annotations to the CITES restrictions on trade in elephants and associated products permits trade (international commercial and non-commercial) in certain specimens of African elephants (including live animals but excluding raw ivory). Trading is allowed by the Convention subject to compliance with certain specified conditions (CITES, 2017; Cusworth, 2017; CITES-b, 2017). Various stakeholders seem opposed to live elephants' trade. Reports assert that baby elephants are brutally captured and kept in enclosures after hunters, using helicopters, separate the youngsters from their herds, leaving them disoriented, exhausted and subdued (GWW - Green World Warriors, 2019).

\section{Poaching and Mitigation Practices}

Poaching is a major threat to tourism and the safety of game rangers (Zhou et al., 2018). The sight of brutally butchered wild animals is disgusting and worrisome. Tourists are put off by such sights. On the other hand, poachers pose a life threat to game rangers when they are on official patrols. Despite the official ban in ivory trade in 1989, there has been a soaring influx of ivory into the Asian markets. The trend is likely to continue if status quo remains. The market for ivory definitely exits and there is proof that it has been growing due to increased exports (Hill, 2015). Illegal ivory sales are flourishing to Hong Kong, Japan, the United States and China, where the black market price of a big bull's pair of tusks can top $£ 30,000$. Between 2013 and 2017, it was found that a total of HK\$560 million (US\$71.4 million) worth of wildlife products - including live and dead animals - with a weight of 1,456 metric tonnes, was seized. These included illegal ivory, pangolin scales and rhino horns, potentially equal to the deaths of 3,000 elephants, 65,000 pangolins and 51 rhinoceros (GWW - Green World Warriors, 2019). With current systems for ivory trade, it is difficult to distinguish between poached and official ivory. According to a census led by EWB, Africa is losing elephants to poachers at an average of one every 15 minutes. The EWB survey report of 2018 reported a total of 1677 carcasses with an estimate of 11,044 in the survey area (Chase, Schlossberg, Sutcliffe, Seonyatseng, 2018). 


\section{PROPOSED SUPPLY CHAIN MODEL}

Modern supply chains are focusing more on responsible sourcing. Responsible sourcing manages social, environmental, economic aspects, and the overall supply chain through production data (van den Brink, Kleijn, Tukker, \& Huisman, 2019). The term 'responsible sourcing' was first introduced in the food and clothing industries (Young, \& Osmani, 2013). Some sustainability schemes have developed a 'chain of custody' model to support traceability in modern supply chains (van den Brink, Kleijn, Tukker, \& Huisman, 2019). Four different 'chain of custody' models in use are: the identity preservation model, the physical segregation model, the mass balance model and the book and claim approach (Mol, \& Oosterveer, 2015).

Supply chain traceability systems are valuable for managing product safety, product recall, and reverse logistics (Dai, Ge, \& Zhou, 2015). Traceability in modern supply chains is achieved through GPS devices, Wi-Fi enabled sensors, RFID tags and blockchain tags (Addo-Tenkorang, Gwangwava, Ogunmuyiwa, \& Ude, 2019). Tracking systems have been used on wildlife to study the spatial ecology in order to develop novel solutions for maintaining and protecting wildlife populations and their environment (EWB, 2019). Movement monitoring provides a baseline of information about animal habitat needs, density and distribution, demography, ecology, behaviour and social organization (Ihwagi, 2018). EWB implemented the large herbivore program, deploying monitoring collars on migratory species, elephants, zebras, buffalos and wildebeest in Botswana, Namibia, Zambia, and along the borders of Angola and Zimbabwe (EWB, 2019).

Another use case for wildlife tracking is for tracing the source of illegal wildlife products using DNA and the destination of illegal shipments through GPS trackers concealed in the illegal shipments. DNA tests can be conducted on seized shipments or on random wares on sale. Using concealed GPS trackers require the authorities to have discovered illegal shipments before they reach their destination. DNA-testing is expensive ('t Sas-Rolfes, Challender, Hinsley, Veríssimo, \& Milner-Gulland, 2019; World Bank Group. 2018). Supply chain tracking initiatives implemented so far have been targeted at cutting the supply chain for ivory. Modern trends can be adopted and implemented to sustain legal supply chains for wildlife and associated products.

\section{Blockchain Technology}

The blockchain technology was introduced as part of the first cryptocurrency, Bitcoin, by a Japanese programmer going by the pseudo name Satoshi Nakamoto (Iansiti, \& Lakhani, 2017; Lemieux, 2016; Yli-Huumo, Ko, Choi, Park, \& Smolander, 2016). The technology has since gained many applications. Today, Blockchain is used in supply chain to provide provenance (strong assurance of origin and chain-of-custody), Recalls (faster and more precise product recalls), Freshness (fresher produce, reduce waste and spoilage), and Safety (fewer contamination incidents) (CR-Chainlink Research, 2018).

At the most basic level, blockchain is a database that provides a platform onto which supply chain transactions can be recorded from the raw source to the finished product. Data about various attributes and processes can be uploaded to the system and validated at the appropriate supply chain points, and then linked to the physical materials using bar codes, tags or other internet of things applications (such as RFID tags). This information can be shared among the authorised blockchain members (suppliers, producers, regulatory authorities, and end user consumers). Blockchain differs from conventional databases in that it allows data to be stored as an immutable 'block' on a collectively owned and distributed digital database (public ledger). Every block is validated based on previous blocks, making it very difficult to alter since modification of a recorded transaction would require modifying all previous blocks.

Pilot projects for blockchain based supply chains are the BeefChain ${ }^{\mathrm{TM}}$, Tracr, and TrustChain. BeefChain ${ }^{\mathrm{TM}}$ is a US-led start-up that aims to create a "rancher-centric" supply chain using blockchain technology. The start-up claims that the platform enables unique animal identification and ensures origin, thus allowing the rancher to receive premium pricing for premium beef, and provides consumers 


\begin{tabular}{|c|c|c|c|c|c|}
\hline Elements ® & \multirow[t]{2}{*}{ Ledger } & \multirow[t]{2}{*}{ Shared } & \multirow[t]{2}{*}{ Decentralized } & \multirow[t]{2}{*}{ Immutable } & \multirow[t]{2}{*}{ Secure } \\
\hline Definition $^{-}$ & & & & & \\
\hline $\begin{array}{l}\text { Blockchain is } \\
\text { a technology } \\
\text { providing an } \\
\text { immutable, } \\
\text { secure, } \\
\text { decentralized, } \\
\text { shared ledger. }\end{array}$ & $\begin{array}{l}\text {-Similar to a } \\
\text { financial ledger, } \\
\text { a blockchain is } \\
\text { an ordered list } \\
\text { of 'transactions.' } \\
\text { Transactions can be } \\
\text { financial } \\
\text { exchanges (as on } \\
\text { bitcoin and other } \\
\text { cryptocurrency } \\
\text { blockchains) or } \\
\text { the record of an } \\
\text { event, such as } \\
\text { a hand-off in a } \\
\text { chain of custody, } \\
\text { the completion } \\
\text { of a task, or even } \\
\text { a temperature } \\
\text { reading at a specific } \\
\text { time and place. } \\
\text { The sequence } \\
\text { of validated } \\
\text { transactions is } \\
\text { strictly maintained. } \\
\text { For } \\
\text { cryptocurrencies, } \\
\text { this prevents } \\
\text { double-spend, as the } \\
\text { oldest transaction } \\
\text { prevails and newer } \\
\text { duplicates are } \\
\text { invalidated. }\end{array}$ & $\begin{array}{l}\text { - The ledger } \\
\text { provides a } \\
\text { common view } \\
\text { (aka } \\
\text { the single-version- } \\
\text { of-the-truth) } \\
\text { across many } \\
\text { parties, } \\
\text { even if they } \\
\text { lack trust or a } \\
\text { longstanding } \\
\text { relationship } \\
\text { (Loop, } 2016\end{array}$ & $\begin{array}{l}\text {-The ledger is } \\
\text { broadly replicated } \\
\text { and verified by a } \\
\text { large number of } \\
\text { different entities. } \\
\text { This } \\
\text { makes blockchains } \\
\text { robust and resistant } \\
\text { to } \\
\text { cyberattacks and } \\
\text { system failures, as } \\
\text { an attacker or } \\
\text { outage would have } \\
\text { to impact a large } \\
\text { portion of the } \\
\text { network of } \\
\text { entities in order to } \\
\text { compromise the } \\
\text { blockchain. } \\
\text { The degree of } \\
\text { decentralization } \\
\text { varies } \\
\text { between different } \\
\text { blockchains, } \\
\text { depending on the } \\
\text { goals and design } \\
\text { (Tian, 2016) }\end{array}$ & $\begin{array}{l}\text { - The ledger } \\
\text { is immutable, } \\
\text { meaning that } \\
\text { transactions } \\
\text { can never by } \\
\text { deleted or } \\
\text { modified. } \\
\text { If there is } \\
\text { an error in a } \\
\text { transaction, } \\
\text { it can only be } \\
\text { corrected by } \\
\text { writing a new } \\
\text { transaction } \\
\text { undoing } \\
\text { the error. } \\
\text { This makes } \\
\text { blockchains } \\
\text { highly } \\
\text { auditable, as } \\
\text { there can be } \\
\text { no after-the- } \\
\text { fact rewriting } \\
\text { without a } \\
\text { clear trail } \\
\text { of what } \\
\text { happened. }\end{array}$ & $\begin{array}{l}\text { - } \\
\text { techyptographic } \\
\text { (e.g. hashes, } \\
\text { digital } \\
\text { signatures) is } \\
\text { used to ensure } \\
\text { there is no } \\
\text { tampering with } \\
\text { the data in the } \\
\text { blockchain. } \\
\text { The way in } \\
\text { which hashes } \\
\text { are used to link } \\
\text { the content of } \\
\text { each block of } \\
\text { transactions } \\
\text { from/to the } \\
\text { previous and } \\
\text { next blocks is } \\
\text { how blockchain } \\
\text { got its name. }\end{array}$ \\
\hline
\end{tabular}

with greater confidence in the meat they consume (Tannam, 2018). De Beers uses Tracr (an immutable and secure digital trail) for a selection of rough diamonds they mined as they move from the mine to cutter and polisher, then through to a jeweller [39]. Pilot tests were on larger diamonds, hence expanding the initiative to smaller diamonds and other supply partners will be a bigger challenge. TrustChain is another jewelry blockchain initiative in the retail industry to protect the security and safety of food supplies, making it possible to quickly trace the origin of food products when food safety issues arise (Hill, 2018).

\section{Concept For Blockchain Supply Chain Tracking in Elephants And Ivory}

Current tracking efforts in wildlife can be expanded to focus on the formal trade rather than crime detection. Customers buying wildlife and associated products need assurance about the legal source, compliance, management tools (sustainable conservation), end-to-end traceability, conservation financing, and customer engagement. These use cases can bring sanity and sustainability to wildlife trading. Shoddy dealings can be eliminated if there is cooperation among all the stakeholders involved. Establishing a coordinated supply chain with end-to-end traceability can effectively inform biodiversity conservation and management. Consumers can be made aware about the value chain for the products they buy and the need to trace the source through QR codes before purchasing. Through blockchain technology, tokens may also be introduced and an enforcement be made for all buyers to use the tokens 
in order to allow traceability. Current wildlife trade remains a myth to many individuals because a lot of information resides with top government officials and customs authorities. A few daring individuals who are conversant with the process have made discoveries through persistent involvement. African Savannah citizens are in the dark because wildlife trade among local communities is prohibited. End user customers also don't have much information since the raw materials for finished products they buy are sourced remotely.

Based on literature review on the current wildlife practices and blockchain initiatives, ivory trade has the following participants;

- Government Authority

- Local Community

- National park and game reserve

- Conservationist

- Tourist

- Hunter

- Wildlife Veterinary

- Law Enforcement

- Certifier

- Customs

- Warehouse/Stockpile

- Distribution

- Port Authority

- Manufacturer

- Wholesaler

- Retailer

- Consumer

The participants can be mapped into a blockchain model as follows;

All participants in the blockchain model are connected together through various nodes. The interconnection helps to clearly identify when ivory wildlife products change hands. Transparency is greatly improved through the blockchain. Data from all the nodes can be posted to the public ledger and can be accessed by relevant blockchain participants in the network.

A typical succession of events from the parks to people can be demonstrated through Figure 2. The figure illustrates a series of countries, starting from the originating country that is custodian of wildlife through parks. The originating country features wildlife management and conservation practices, as well as various actors who implement the approved wildlife practices. The appropriate wildlife harvesting occurs in the originating country A. Data that needs to be captured in block 1 by the originating country includes the wildlife resource, origin, quantity, grade, and provenance of the harvested resource. Block 2 captures certification data after verifying the authenticity of data captured in block 1 . Once all the data is verified and validated, the wildlife resource can be authorised for shipment to another destination for further processing. This requires completion of bill of lading certificate. Value addition processes are carried out in subsequenty countries, and the goods are passed on until they reach final destination for sale to consumers. This sequence completes the chain of events from parks to people (consumers).

\section{DISCUSSION}

The traditional centralised supply chain of wildlife products, as shown in Figure 3, follows a series of linear interactions between the various stakeholders. Typical transactions pass from local communities 


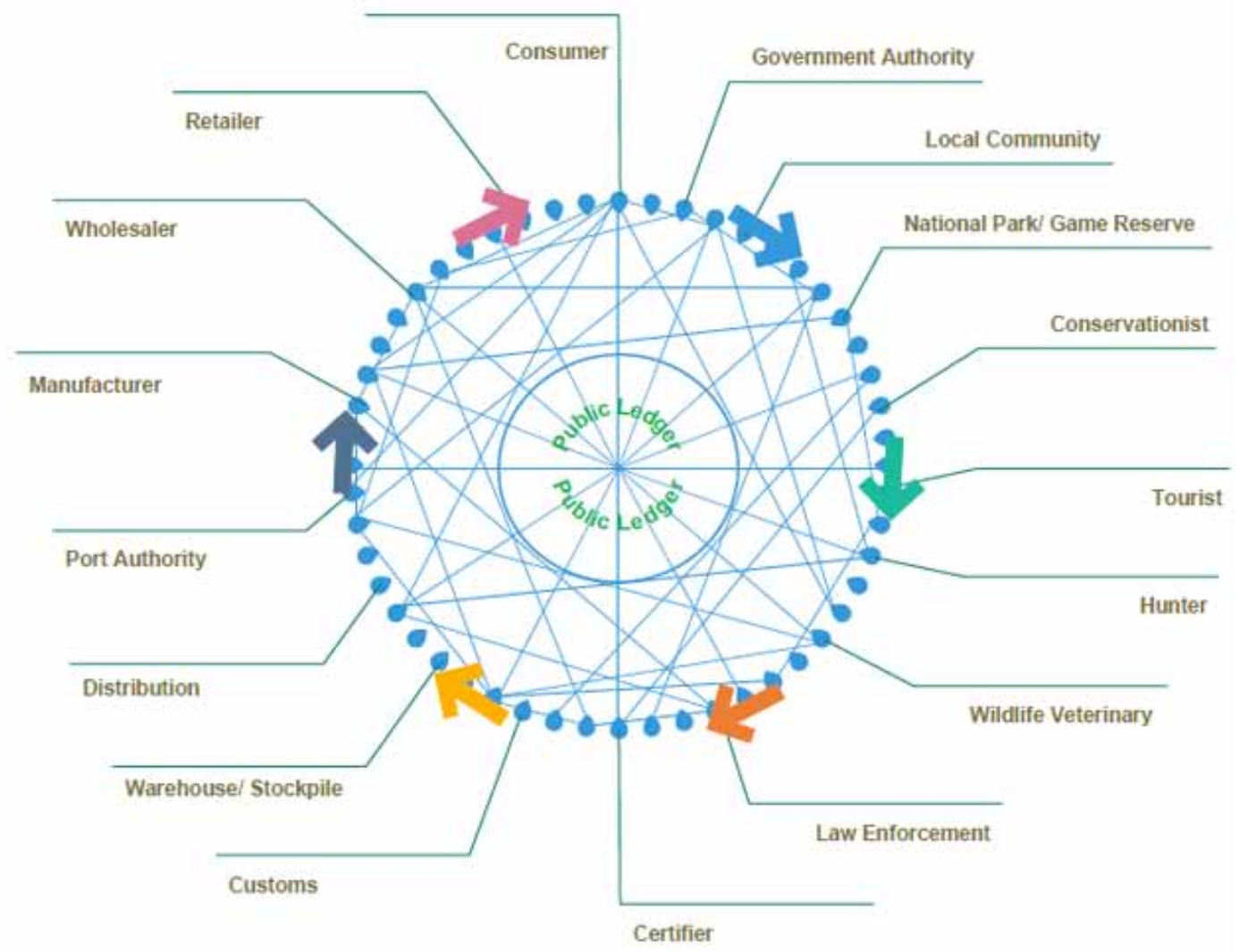

who live in wildlife prone areas, government authorities who regulate wildlife practices, foreign investors with interest in wildlife management, conservation and tourism, parks and or game reserves to wildlife wardens and hunters, transporters, ports, customs, manufacturers, wholesalers, retailers, and consumers. The illegal route is illustrated by the red dotted line. Illegal transactions are executed by poachers and passed on through middlemen to transporters. Because of lack of official tracking methods, the transporters pass on the illegal goods into the formal channel from the manufacturer, through to wholesalers, retailers and consumers. Verification of transactions and shipments end at ports and customs whilst the shipment is in its raw form. Information in the traditional supply chain can be altered or communicated inaccurately along the way.

On the contrary, the blockchain model ensures that all transactions between each stage are verified by a trusted third party. The flow of information across the network relies upon the accurate passing of information between stakeholders and depends on trust from stakeholder to stakeholder. The blockchain model (as shown in Figure 1) features a decentralised supply chain, with all stakeholders connected via the blockchain network. Transactions and information are stored and verified by all users, and all stakeholders are equally connected. The blockchain approach can address the following concerns:

- Sustainable Conservation Assurance

Wildlife conservationists, government authorities in wildlife originating countries, wildlife activists, and local residents in wildlife prone areas are currently at logger heads concerning best 
Figure 2. Ivory blockchain - from parks to people

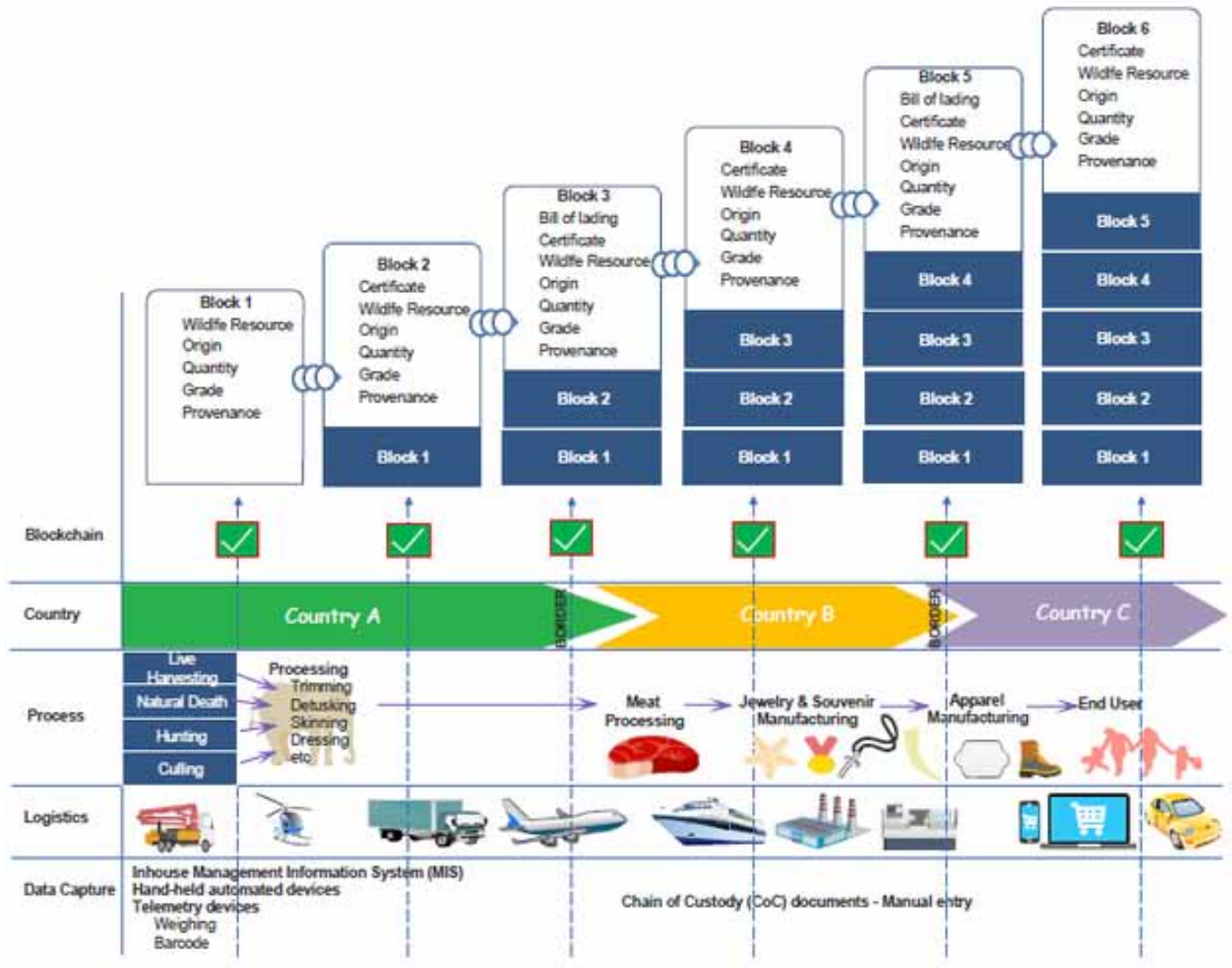

Figure 3. Traditional ivory supply chain

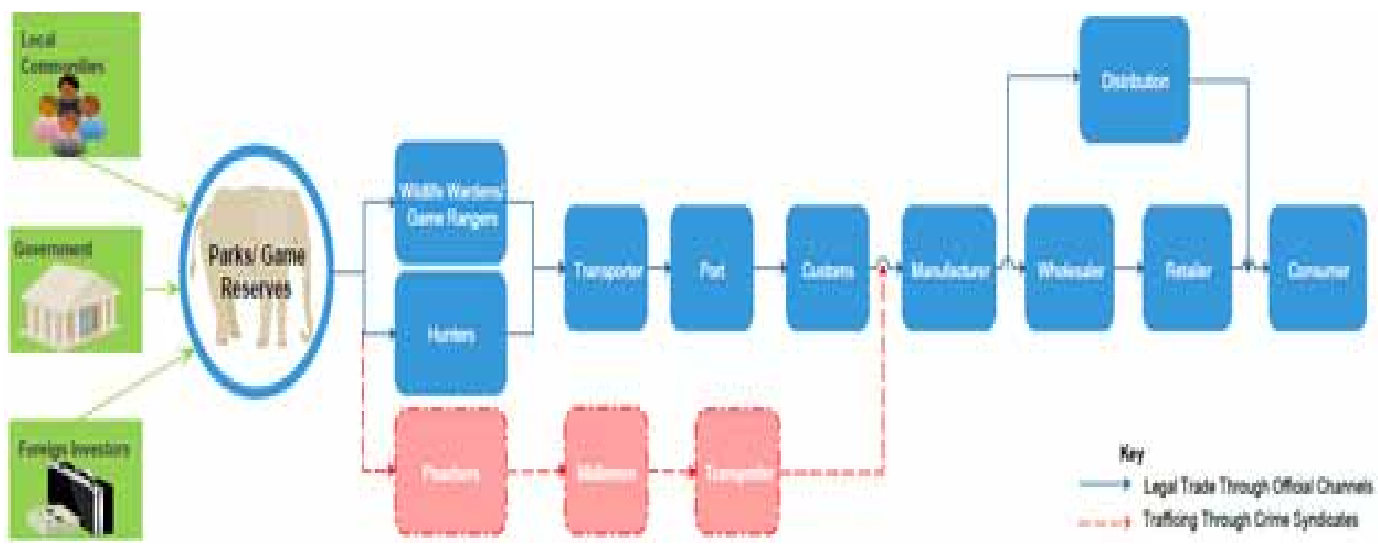

practices for wildlife management. The debates have been heated up to extents of bans in wildlife trading. The blockchain can bring all concerned parties together and balance up all the genuine concerns. This will give assurance of sustainable conservation practices throughout the supply chain. 


\section{- End-to-end blockchain traceability}

Blockchain assures traceability throughout the supply chain - from parks to people. Verification, validation and certification throughout all the nodes can pick up non-compliance.

\section{- Conservation / Wildlife Management Finance}

Wildlife conservation and management finances can be easily managed through a decentralised public blockchain. Current practice is hidden from many players who may be interested in knowing details of sourcing and disbursement of conservation finances.

\section{- Consumer engagement}

Consumers of wildlife products in the traditional supply chain have no information about the original source of the products they buy. Customers need to be engaged throughout the chain. This would help consumers to buy products from an informed position. Consumers can also use the blockchain network to provide feedback about product quality and also express their views concerning conservation practices.

\section{- Certification}

Wildlife is highly regulated but currently lacks formal documentation and traceability. The established systems can be used to enhance certification, storage, management and sharing of regulatory documents across the blockchain network.

\section{CONCLUSION}

The article pursued thorough literature review about wildlife resource conservation, particularly African elephants. Unlike other abundant resources, African elephants fall under endangered species which are threatened by extinction. African and International governments are heavily involved in finding an amicable position as far as wildlife management is concerned. The nature of African economies is that of dependency on primary resource extraction and harvesting. The threatening extinction of the African elephant triggered various responses ranging from ivory trade ban to trophy hunting ban or discouragement. There is also a threat from illegal poaching. Africa generally feels let down by the international community in terms of the harsh measures to ban trade of ivory, discouragement of trophy hunting and live wildlife trading. If the market for wildlife and products is cut off, Africa will be stuck with valueless ivory, for instance. There is already a foul cry over dwindling income streams to support sustainable wildlife conservation. The only possible inflows will be through tourism. Another challenge is the life threat posed by wildlife to expanding African human population, particularly locals residing in around wildlife abundant areas. This poses serious human-wildlife conflict. Many villagers can vividly recite horrific wildlife-human classes, most of them which have been fatal. The article therefore brings in a sustainable approach to manage the dire situation. Lack of transparency have triggered extreme responses from both African governments and the international states. The blockchain can rebuild trust and ensure sustainability in the wildlife resource management practices. Due to resources limitations, the proposed model could not be programmed on the blockchain. Future efforts will be directed towards developing the blockchain and pilot deployment of the system to test its applicability. 


\section{REFERENCES}

Addo-Tenkorang, R., Gwangwava, N., Ogunmuyiwa, E. N., \& Ude, A. U. (2019). Advanced Animal Track-\&-Trace Supply-Chain Conceptual Framework: An Internet of Things Approach. Procedia Manufacturing, 30, 56-63.

Bennett, E. L. (2015). Legal ivory trade in a corrupt world and its impact on African elephant populations. Conservation Biology, 29(1), 54-60. doi:10.1111/cobi.12377 PMID:25103555

Bertschinger, H. J., Kirkpatrick, J. F., Fayrer-Hosken, R. A., Grobler, D., \& Van Altena, J. J. (2003). Immunocontraception of African elephants using porcine zona pellucida vaccine. In Proceedings of the First Workshop on the Control of Wild Elephant Populations. Utrecht University.

Biggs, H. C., Slotow, R., Scholes, B., Carruthers, J., Van Aarde, R., Kerley, G., Twine, W., Grobler, D., Bertschinger, H., Grant, C., \& Lötter, H. (2008). Towards integrated decision-making for elephant management. Assessment of South African Elephant Management, 537-586.

Brennan, A. J., \& Kalsi, J. K. (2015). Elephant poaching \& ivory trafficking problems in Sub-Saharan Africa: An application of O'Hara's principles of political economy. Ecological Economics, 120, 312-337. doi:10.1016/j. ecolecon.2015.08.013

Chase, M., Schlossberg, S., Sutcliffe, R., \& Seonyatseng, E. (2018). Dry Season Aerial Survey Of Elephants And Wildlife In Northern Botswana July - October 2018. Final Draft. Available: http://elephantswithoutborders.org/ site/wp-content/uploads/2018-Botswana-report-final-version-compressed-upload.pdf

Chase, M. J., Schlossberg, S., Griffin, C. R., Bouché, P. J., Djene, S. W., Elkan, P. W., Ferreira, S., Grossman, F., Kohi, E. M., Landen, K., Omondi, P., Peltier, A., Selier, S. A. J., \& Sutcliffe, R. (2016). Continent-wide survey reveals massive decline in African savannah elephants. PeerJ, 4, e2354. doi:10.7717/peerj.2354 PMID:27635327

CITES. (2017a). Appendices I, II And III. Available: https://cites.org/sites/default/files/eng/app/2017/EAppendices-2017-10-04.pdf

CITES. (2017b). Challenges To Cites Regulation Of The International Trade In Live, Wild-Caught African Elephants. Sixty-ninth meeting of the Standing Committee. Available: https://cites.org/sites/default/files/eng/ com/sc/69/inf/E-SC69-Inf-36.pdf

CR-Chainlink Research. (2018). Available: https://www.zestlabs.com/wp-content/uploads/2018/01/BlockchainsRole-in-the-Produce-Supply-Chain.pdf

Cumming, D., \& Jones, B. (2005). Elephants in southern Africa: Management issues and options. WWF-SARPO Occasional Paper No. 11. http://d2ouvy59p0dg6k.cloudfront.net/downloads/cumming___jones_2005 elephants_in_sthn_africa__mgmt_options__issues_wwf_sarpo_occ_.pdf

Cusworth, J. (2017). Barriers To Sustainable Hunting-Based Conservation Of Elephants In Zimbabwe. Clark Digital Commons. Available: https://commons.clarku.edu/idce_masters_papers/118/

Dai, H., Ge, L., \& Zhou, W. (2015). A design method for supply chain traceability systems with aligned interests. International Journal of Production Economics, 170, 14-24.

Duffy, R. (2014). Interactive elephants: Nature, tourism and neoliberalism. Annals of Tourism Research, 44, 88-101. doi:10.1016/j.annals.2013.09.003

EWB. (2019). Elephants Without Borders Response to Press Release by: Permanent Secretary, Mr. Thato Raphaka Ministry of Environment, Natural Resources Conservation and Tourism 24 February 2019. Available: http:// elephantswithoutborders.org/site/wp-content/uploads/Response-to-PS-Press-Release-240219-EWB-FINAL.pdf

GWW (Green World Warriors). (2019). Customs urged to step up prosecutions in illegal wildife trade - with blood of 3,000 elephants, 65,000 pangolins and 51 rhinoceros on Hong Kong's hands. Green World Worriors. https://greenworldwarriors.com/2019/02/04/customs-urged-to-step-up-prosecutions-in-illegal-wildlife-tradewith-blood-of-3000-elephants-65000-pangolins-and-51-rhinoceros-on-hong-kongs-hands/

Hill, A. (2018). The Jewelry Industry Prepares For Supply Chain Trace-Ability. Forbes. Available: https:// www.forbes.com/sites/andreahill/2018/10/07/the-jewelry-industry-prepares-for-supply-chain-trace-

ability/\#3c7eb0f35e2e 
Hill, J. F. (2015). A systems thinking perspective on the motivations and mechanisms that drive wildlife poaching. In Green Harms and Crimes (pp. 189-219). Palgrave Macmillan.

Iansiti, M., \& Lakhani, K. (2017). The Truth About Blockchain. Harvard Business Review, 95(1), 118-127.

Ihwagi, F. W., Thouless, C., Wang, T., Skidmore, A. K., Omondi, P., \& Douglas-Hamilton, I. (2018). Night-day speed ratio of elephants as indicator of poaching levels. Ecological Indicators, 84, 38-44.

Kalikawe, M. C. (2001). Botswana: Integrating biodiversity into the tourism sector. In A presentation made to the UNEP International Workshop on Best Practices and Country Case Studies, Mexico City (pp. 29-31). Available: https://www.cbd.int/doc/nbsap/tourism/BOTSWANA(Tourism).pdf

Lemieux, V. L. (2016). Trusting records: Is Blockchain technology the answer? Records Management Journal, 26(2), 110-139.

Mbaiwa, J. E. (2008). The realities of ecotourism development in Botswana. Responsible tourism: Critical issues for conservation and development, 205-223.

McKenzie, D., \& Formanek, I. (2016). Study Shows Tragic Drop In African Elephants. CNN. Available: https:// edition.cnn.com/2016/08/31/africa/great-elephant-census/index.html

Mol, A. P., \& Oosterveer, P. (2015). Certification of markets, markets of certificates: Tracing sustainability in global agro-food value chains. Sustainability, 7(9), 12258-12278.

Muposhi, V. K., Gandiwa, E., Bartels, P., \& Makuza, S. M. (2016). Trophy hunting, conservation, and rural development in Zimbabwe: Issues, options, and implications. International Journal of Biodiversity. doi: $10.1155 / 2016 / 8763980$

Pinnock, D. (2019). Elephant Poaching: Syndicates Move South; Botswana President Calls It Fake News. Daily Maverick. Available: https://www.dailymaverick.co.za/article/2019-02-25-syndicates-move-south-botswanapresident-calls-it-fake-news/

Seloana, M. Q., Kruger, J. W., Potgieter, M. J., \& Jordaan, J. J. (2017). Elephant damage to Sclerocarya birrea on different landscapes. International Journal of Biodeversity and Conservation, 9(4), 97-106. doi:10.5897/ IJBC2015.0912

Seloana, M. Q., Potgieter, M. J., Kruger, J. W., \& Jordaan, J. J. (2017). Elephant Management Plan Outputs. Scientific Journal of Forest Research, 1(1), 13-31.

Stiles, D. (2004). The ivory trade and elephant conservation. Environmental Conservation, 31(4), 309-321. doi: $10.1017 /$ S0376892904001614

't Sas-Rolfes, M., Challender, D. W., Hinsley, A., Veríssimo, D., \& Milner-Gulland, E. J. (2019). Illegal wildlife trade: Scale, processes, and governance. Annual Review of Environment and Resources, 44, 201-228.

Tannam, E. (2018). How Could Blockchain Transform The Irish Beef Industry? Silicon Republic. Available: https://www.siliconrepublic.com/enterprise/blockchain-beef-industry-deloitte

Thalefang, C. (2018). How Many Elephants Are There In Botswana? Available: http://www.mmegi.bw/index. php?aid=76789\&dir=2018/july/27

van den Brink, S., Kleijn, R., Tukker, A., \& Huisman, J. (2019). Approaches to responsible sourcing in mineral supply chains. Resources, Conservation and Recycling, 145, 389-398.

Vigne, L., \& Martin, E. (2018). Myanmar's Growing Illegal Ivory Trade With China. Google Docs. Available: https://drive.google.com/file/d/16Cuj54hZKZWIGvnHfSoOQJ8rK_5VN6ib/view

Vilkos, Y. (2018). De Beers Group Successfully Tracks First Diamonds From Mine To Retail On Industry Blockchain. Available: https://www.debeersgroup.com/media/company-news/2018/de-beers-group-successfullytracks-first-diamonds-from-mine-to-r

Winters, M., Torkelson, A., Booth, R., Mailand, C., Hoareau, Y., Tucker, S., \& Wasser, S. K. (2018). Isolation of DNA from small amounts of elephant ivory: Sampling the cementum with total demineralization extraction. Forensic Science International, 288, 131-139. 
World Bank Group. (2018). Tools and resources to combat illegal wildlife trade. Available: https://pubdocs. worldbank.org/en/389851519769693304/24691-Wildlife-Law-Enforcement-002.pdf

Yli-Huumo, J., Ko, D., Choi, S., Park, S., \& Smolander, K. (2016). Where Is Current Research On Blockchain Technology?-A Systematic Review. PLoS One, 11(10), e0163477.

Young, J., \& Osmani, M. (2013). Investigation into contractors' responsible sourcing implementation practice. Proceedings of the Institution of Civil Engineers. Engineering Sustainability, 166(6), 320-329.

Zhou, X., Wang, Q., Zhang, W., Jin, Y., Wang, Z., Chai, Z., Zhou, Z., Cui, X., \& MacMillan, D. C. (2018). Elephant poaching and the ivory trade: The impact of demand reduction and enforcement efforts by China from 2005-2017. Global Ecology and Conservation, 16, e00486. 